Article

\title{
Hydrogen Production from Ammonia Borane over PtNi Alloy Nanoparticles Immobilized on Graphite Carbon Nitride
}

\author{
Mingya Zhang ${ }^{1}$, Xue Xiao ${ }^{1,2}$, Yan $\mathrm{Wu}^{2}$, Yue $\mathrm{An}^{3}$, Lixin $\mathrm{Xu}^{2,4}$ and Chao Wan ${ }^{2,3,4, *(\mathbb{D})}$ \\ 1 Key Laboratory of Metallurgical Emission Reduction \& Resources Recycling, Ministry of Education, \\ School of Metallurgical Engineering, Anhui University of Technology, Ma'anshan 243002, China; \\ ahutzmh@163.com (M.Z.); xx1998salung@163.com (X.X.) \\ 2 School of Chemistry and Chemical Engineering, Anhui Province Key Laboratory of Coal Clean Conversion \\ and High Valued Utilization, Anhui University of Technology, Ma'anshan 243002, China; \\ wuyan9712@163.com (Y.W.); lxxu@hotmail.com (L.X.) \\ 3 College of Chemical and Biological Engineering, Zhejiang University, Hangzhou 310027, China; \\ zju.anyue@hotmail.com \\ 4 Ahut Chemical Science \& Technology Co., Ltd., Ma'anshan 243002, China \\ * Correspondence: wanchao1219@hotmail.com; Tel.: +86-555-2311807; Fax: +86-555-2311822
}

Received: 31 October 2019; Accepted: 29 November 2019; Published: 1 December 2019

\begin{abstract}
Graphite carbon nitride $\left(\mathrm{g}-\mathrm{C}_{3} \mathrm{~N}_{4}\right)$ supported PtNi alloy nanoparticles (NPs) were fabricated via a facile and simple impregnation and chemical reduction method and explored their catalytic performance towards hydrogen evolution from ammonia borane $(\mathrm{AB})$ hydrolysis dehydrogenation. Interestingly, the resultant $\mathrm{Pt}_{0.5} \mathrm{Ni}_{0.5} / \mathrm{g}-\mathrm{C}_{3} \mathrm{~N}_{4}$ catalyst affords superior performance, including $100 \%$ conversion, $100 \% \mathrm{H}_{2}$ selectivity, yielding the extraordinary initial total turnover frequency (TOF) of $250.8 \mathrm{~mol}_{\mathrm{H} 2} \mathrm{~min}^{-1}\left(\mathrm{~mol}_{\mathrm{Pt}}\right)^{-1}$ for hydrogen evolution from $\mathrm{AB}$ at $10{ }^{\circ} \mathrm{C}$, a relatively low activation energy of $38.09 \mathrm{~kJ} \mathrm{~mol}^{-1}$, and a remarkable reusability (at least 10 times), which surpass most of the noble metal heterogeneous catalysts. This notably improved activity is attributed to the charge interaction between PtNi NPs and g- $\mathrm{C}_{3} \mathrm{~N}_{4}$ support. Especially, the nitrogen-containing functional groups on $\mathrm{g}-\mathrm{C}_{3} \mathrm{~N}_{4}$, serving as the anchoring sites for PtNi NPs, may be beneficial for becoming a uniform distribution and decreasing the particle size for the NPs. Our work not only provides a cost-effective route for constructing high-performance catalysts towards the hydrogen evolution of $\mathrm{AB}$ but also prompts the utilization of $\mathrm{g}-\mathrm{C}_{3} \mathrm{~N}_{4}$ in energy fields.
\end{abstract}

Keywords: ammonia borane; $\mathrm{PtNi} / \mathrm{g}-\mathrm{C}_{3} \mathrm{~N}_{4}$; hydrogen storage; dehydrogenation

\section{Introduction}

With the ever-growing consumption of fossil energy, accompanied with serious environmental issues, searching for green, sustainable, abundant, and alternative energy sources is of burgeoning urgency [1,2]. Hydrogen, as a clean energy source, has attracted significant research interest owing to its distinctive merits such as producing only water as a by-product and possessing more energy density than that of fossil fuels [3-5]. However, hydrogen, possessing the feature of low density, makes it difficult to liquefy and compress, thus hindering the large-scale applications [4-6]. Therefore, the exploration and seek for hydrogen storage materials with outstanding performance remains a challenging issue.

Tremendous efforts, in the past decades, have been made to explore and design hydrogen storage materials such as hydrazine, formic acid, and ammonia borane and so forth [7-13]. Among various hydrogen storage materials conducted, ammonia borane $(\mathrm{AB})$, a white solid with excellent 
stability at room temperature and high hydrogen content (19.6 wt \%), has aroused considerable interest as a promising hydrogen storage material $[14,15]$. There are two main approaches for $\mathrm{AB}$ to release hydrogen: (i) thermal dehydrogenation and (ii) hydrolytic dehydrogenation [14-16]. However, compared with thermal dehydrogenation, proceeding under high temperature, hydrolysis dehydrogenation process is easier to accomplish the industrial application under mild conditions [15-17]. With the aid of the suitable catalyst, $1 \mathrm{~mol}$ of $\mathrm{AB}$ can be controlled to release $3 \mathrm{~mol}$ of hydrogen under moderate conditions. The catalytic hydrolysis reaction can be described in detail as follows [18-22]:

$$
\mathrm{NH}_{3} \mathrm{BH}_{3}(\mathrm{aq})+2 \mathrm{H}_{2} \mathrm{O}(\mathrm{l}) \stackrel{\text { Catalyst }}{\rightarrow} \mathrm{NH}_{4} \mathrm{BO}_{2}(\mathrm{aq})+3 \mathrm{H}_{2}(\mathrm{~g})
$$

In recent years, a large number of supported metal catalysts including noble metal and non-noble metal, have been constructed for the hydrolysis of $\mathrm{AB}$, among which Pt-based noble catalysts, as one of the most studied catalysts both in industrial and scientific fields, demonstrate more extraordinary catalytic performance than that of other metal catalysts for hydrolysis of AB [20-27]. However, the features of $\mathrm{Pt}$ with its high prices and limited reserves severely restrict its extensive utilization of $\mathrm{Pt}$ metal as the catalyst [27-29]. Currently, to actually reduce the utilization amount of $\mathrm{Pt}$, assembling with the enhancement of catalysts, the fabrication of Pt alloy nanomaterials, especially coupling with the noble-free metals, such as $\mathrm{Fe}, \mathrm{Co}, \mathrm{Ni}$, etc., has been identified to be an effective approach due to its structural and electronic effects [30-33]. Previous studies have revealed that Pt-M bimetallic catalysts could display higher catalytic activity than that of their single counterparts as well as lower cost [32-36]. For instance, Han et al. applied a chemical reduction route to synthesize amino modified $\mathrm{SiO}_{2}$ nanospheres supported CoPt-Co hybrid at $278 \mathrm{~K}$, affording a turnover frequency (TOF) value of $25.59 \mathrm{~mol}_{\mathrm{H} 2} \mathrm{~min}^{-1} \mathrm{~mol}_{\mathrm{M}}{ }^{-1}$, almost two-fold as high as that of unsupported $\mathrm{Pt}_{0.1} \mathrm{Co}_{0.9}$ nanoparticles (NPs) [37]. Xu et al. fabricated hierarchical nanoporous $\mathrm{PtCu}$ alloy nanoflowers by means of the two-step dealloying method with a maximum TOF value up to $108 \mathrm{~mol}_{\mathrm{H} 2} \mathrm{~min}^{-1} \mathrm{~mol}_{\mathrm{M}}{ }^{-1}$ [38]. Lu et al. reported the synthesis of $\mathrm{PtNi} / \mathrm{NiO}$ clusters coated by hollow silica using atomic sacrifice method, reaching a TOF of $1240.3 \mathrm{~mol}_{\mathrm{H} 2} \mathrm{~min}^{-1} \mathrm{~mol}_{\mathrm{Pt}^{-1}}$ [39]. However, Pt-M NPs are readily tending to aggregate to form a bigger particle, resulting in a momentous decrease in the catalytic performance including activity, stability, and efficiency. Therefore, in order to obtain high catalytic performance for hydrolytic dehydrogenation of $\mathrm{AB}$, considerable effort has been devoted to fabricate high efficiency catalysts involving many types of supporting materials.

It is noted that assembling alloy with appropriate supports, such as metal oxides, carbon nanotubes, mesoporous carbon nitride, graphene, etc., emerges as one of the novel encouraging approaches to further improve the catalytic activities and stability [39-46]. It is well known that the supporting materials play a critical role in enhancing its catalytic properties due to the synergistic effects between alloy and supports. Graphitic carbon nitride $\left(\mathrm{g}-\mathrm{C}_{3} \mathrm{~N}_{4}\right)$, a promising two-dimensional non-metal material, is regarded as a promising candidate owing to its attractive electronic structure, high nitrogen content, excellent chemical and thermal stability, and environment friendliness [45-48]. Chen et al. constructed $\mathrm{Au}-\mathrm{Co}$ nanoparticles $(\mathrm{Au}-\mathrm{Co} @ \mathrm{CN})$, displaying exceedingly good catalytic activity with a TOF value reaching $2897 \mathrm{~mol} \mathrm{H}_{2} \mathrm{~mol}_{\text {metal }}{ }^{-1} \mathrm{~h}^{-1}$ at $298 \mathrm{~K}$ [49]. Fan et al. reported the in-situ construction of g- $\mathrm{C}_{3} \mathrm{~N}_{4}$ supported Rh NPs, giving a very high TOF value of $969 \mathrm{~mol} \mathrm{H}_{2} \mathrm{~mol}_{\mathrm{Rh}}{ }^{-1} \mathrm{~h}^{-1}$ [50]. Encouraged by these achievements, the construction of PtNi alloy anchored into g- $\mathrm{C}_{3} \mathrm{~N}_{4}$ for hydrogen production from the hydrolysis of $\mathrm{AB}$ is of paramount significance and has rarely been reported. Additionally, investigating the construction of bi-metal NPs in $\mathrm{g}-\mathrm{C}_{3} \mathrm{~N}_{4}$ as well as the exploration of the synergistic effect between them are also of outmost importance.

Hence, in this work, we focused on the construction of PtNi with different ratios immobilized on g- $\mathrm{C}_{3} \mathrm{~N}_{4}$, preparing via the direct pyrolysis of melamine under nitrogen atmosphere [51,52], through a simple impregnation and co-reduction method under an ambient atmosphere. The resulting materials were evaluated as catalysts towards the hydrogen production from AB hydrolysis dehydrogenation under mild conditions. The influence of some parameters, such as metal concentration, catalyst 
concentration, $\mathrm{AB}$ concentration, and reaction temperature, on the catalytic performance of $\mathrm{PtNi} / \mathrm{g}-\mathrm{C}_{3} \mathrm{~N}_{4}$ were conducted in detail. Especially, the $\mathrm{Pt}_{0.5} \mathrm{Ni}_{0.5} / \mathrm{g}-\mathrm{C}_{3} \mathrm{~N}_{4}$ demonstrates optimal catalytic performance for the hydrolysis of $\mathrm{AB}$ compared with the samples of other molar ratios of PtNi. Furthermore, the stability of the optimum catalyst was investigated as well.

\section{Results and Discussion}

The synthesis process of PtNi/g- $C_{3} \mathrm{~N}_{4}$ is schematically emerged in Scheme 1. Typically, $g-C_{3} \mathrm{~N}_{4}$ was prepared via a direct pyrolysis route employing melamine as precursor. Then, the $\mathrm{Pt}$ and $\mathrm{Ni}$ precursor with different contents immobilized on $\mathrm{g}-\mathrm{C}_{3} \mathrm{~N}_{4}$ was fabricated, using a simple impregnation and reduction process, where sodium borohydride is employed as a reducing agent, and then applied as catalysts towards hydrogen production of $\mathrm{AB}$. The accurate composition of $\mathrm{PtNi} / \mathrm{g}-\mathrm{C}_{3} \mathrm{~N}_{4}$ was analyzed by inductively coupled plasma atomic emission spectroscopy (ICP-AES), which were close to their desired contents (Table S1). Elemental analysis revealed that the composition of $\mathrm{C}, \mathrm{H}$, and $\mathrm{N}$ of $\mathrm{g}-\mathrm{C}_{3} \mathrm{~N}_{4}$ was $34.71 \mathrm{wt} \%, 1.89 \mathrm{wt} \%$, and $61.47 \mathrm{wt} \%$, respectively. As displayed in Table S1, Figure S1, the Brunner-Emmet-Teller (BET) specific areas of PtNi/g- $\mathrm{C}_{3} \mathrm{~N}_{4}$ was around $10 \mathrm{~m}^{2} / \mathrm{g}$, which was close to the values reported in the literature [51,52]. Figure 1 shows the $X R D$ patterns of $\mathrm{PtNi} / \mathrm{g}-\mathrm{C}_{3} \mathrm{~N}_{4}$ with different contents.

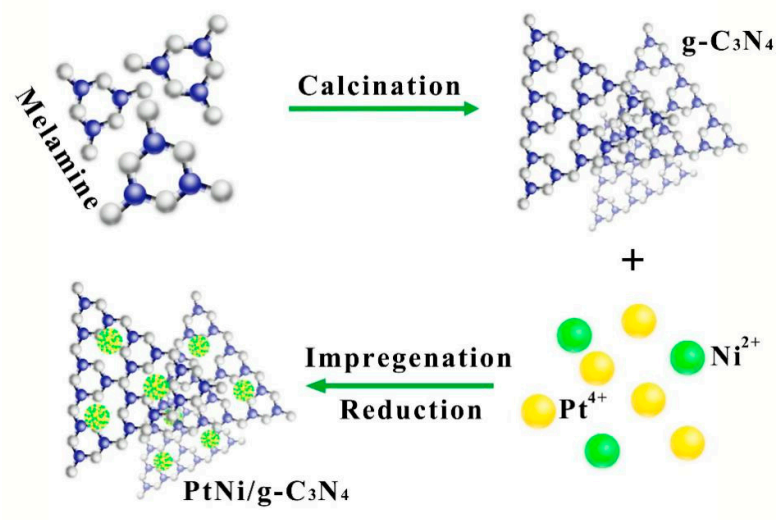

Scheme 1. Schematic illustration of the fabrication of $\mathrm{PtNi} / \mathrm{g}-\mathrm{C}_{3} \mathrm{~N}_{4}$.

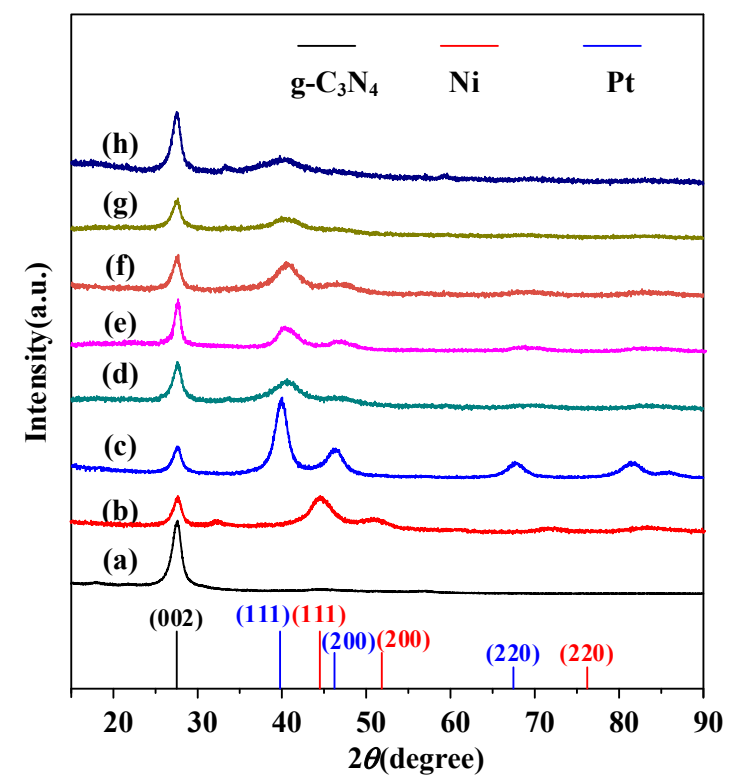

Figure 1. XRD patterns of $\mathrm{PtNi} / \mathrm{g}-\mathrm{C}_{3} \mathrm{~N}_{4}$ composites with different molar ratio of $\mathrm{PtNi}$ : (a) g- $\mathrm{C}_{3} \mathrm{~N}_{4}$, (b) $\mathrm{Ni} / \mathrm{g}-\mathrm{C}_{3} \mathrm{~N}_{4}$ ，(c) $\mathrm{Pt} / \mathrm{g}-\mathrm{C}_{3} \mathrm{~N}_{4}$ ，(d) $\mathrm{Pt}_{0.8} \mathrm{Ni}_{0.2} / \mathrm{g}-\mathrm{C}_{3} \mathrm{~N}_{4}$ ，(e) $\mathrm{Pt}_{0.6} \mathrm{Ni}_{0.4} / \mathrm{g}-\mathrm{C}_{3} \mathrm{~N}_{4}$ ，(f) $\mathrm{Pt}_{0.5} \mathrm{Ni}_{0.5} / \mathrm{g}-\mathrm{C}_{3} \mathrm{~N}_{4}$ ， (g) $\mathrm{Pt}_{0.4} \mathrm{Ni}_{0.6} / \mathrm{g}-\mathrm{C}_{3} \mathrm{~N}_{4}$, and (h) $\mathrm{Pt}_{0.2} \mathrm{Ni}_{0.8} / \mathrm{g}-\mathrm{C}_{3} \mathrm{~N}_{4}$. 
It is evident that a strong peak at $27.5^{\circ}$ for all samples was attributed to the (200) plane of $g-C_{3} \mathrm{~N}_{4}$. For Ni/g- $\mathrm{C}_{3} \mathrm{~N}_{4}$, other than the characteristic peak of $\mathrm{g}-\mathrm{C}_{3} \mathrm{~N}_{4}$, there were three peaks centered at $44.5^{\circ}$, $51.8^{\circ}$, and $76.4^{\circ}$, respectively, which could be ascribed to the (111), (200), and (220) planes of Ni (JCPDS no: 65-0380). For Pt/g- $\mathrm{C}_{3} \mathrm{~N}_{4}$, three peaks at $39.8^{\circ}, 46.2^{\circ}$, and $67.5^{\circ}$ were assigned to the (111), (200), and (220) planes of Pt (JCPDS no: 65-2868). Furthermore, it was evident that a shift to a higher angle compared to that of the $\mathrm{Pt}$ (111) peak in $\mathrm{Pt} / \mathrm{g}-\mathrm{C}_{3} \mathrm{~N}_{4}$, indicating that $\mathrm{PtNi}$ existed in the form of an alloy, which was consistent with the previous literatures yet reported [39,53-55]. The chemical structures of g- $\mathrm{C}_{3} \mathrm{~N}_{4}, \mathrm{Pt} / \mathrm{g}-\mathrm{C}_{3} \mathrm{~N}_{4}, \mathrm{Ni} / \mathrm{g}-\mathrm{C}_{3} \mathrm{~N}_{4}$, and $\mathrm{Pt}_{0.5} \mathrm{Ni}_{0.5} / \mathrm{g}-\mathrm{C}_{3} \mathrm{~N}_{4}$ were further investigated by Fourier transform infrared (FTIR), as presented in Figure 2. A similar FT-IR spectra could be observed for all samples. An obvious absorption peak centered at $810 \mathrm{~cm}^{-1}$ for all samples was ascribed to the bending vibration of the s-triazine ring. A series of peaks detected in $1200-1600 \mathrm{~cm}^{-1}$ were identified as the stretching modes of aromatic $\mathrm{CN}$ heterocycles. In addition, the broad absorption ranging from 3000 to $3400 \mathrm{~cm}^{-1}$ was attributed to the stretching mode of $\mathrm{O}-\mathrm{H}$ (adsorbed water molecules) and $\mathrm{N}-\mathrm{H}$ (amino groups) [31-36,51,52].

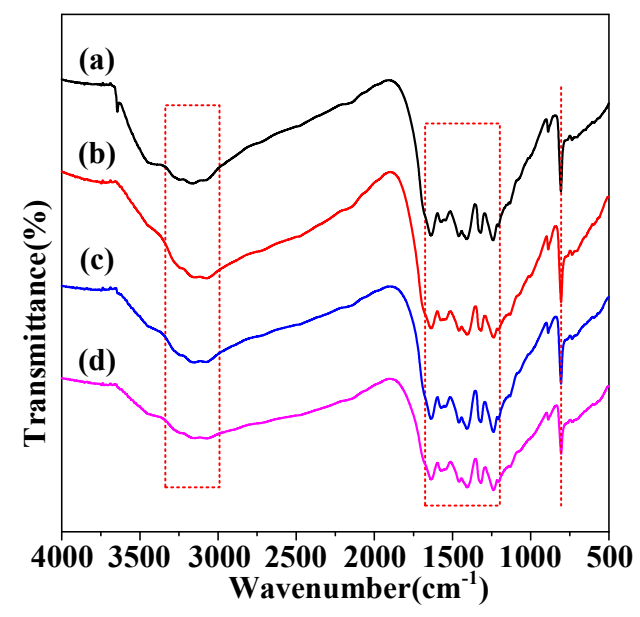

Figure 2. FT-IR spectra of (a) $g-\mathrm{C}_{3} \mathrm{~N}_{4}$, (b) $\mathrm{Pt} / \mathrm{g}-\mathrm{C}_{3} \mathrm{~N}_{4}$, (c) $\mathrm{Ni} / \mathrm{g}-\mathrm{C}_{3} \mathrm{~N}_{4}$, and (d) $\mathrm{Pt}_{0.5} \mathrm{Ni}_{0.5} / \mathrm{g}-\mathrm{C}_{3} \mathrm{~N}_{4}$.

To gain the valence state of $\mathrm{Pt}$ and $\mathrm{Ni}, \mathrm{X}$-ray photoelectron spectroscopy (XPS) analysis was employed for $\mathrm{Pt}_{0.5} \mathrm{Ni}_{0.5} / \mathrm{g}-\mathrm{C}_{3} \mathrm{~N}_{4}$, and the result is illustrated in Figure 3, which presents the characteristic peaks for $\mathrm{Pt}$ and $\mathrm{Ni}$, thus implying the coexistence of both metals. The binding energy (BE) of $\mathrm{C}$ and $\mathrm{N}$ in $\mathrm{Pt}_{0.5} \mathrm{Ni}_{0.5} / \mathrm{g}-\mathrm{C}_{3} \mathrm{~N}_{4}$ were in accordance with the previous reported literatures about $\mathrm{g}-\mathrm{C}_{3} \mathrm{~N}_{4}$ (Figure S2) [50-52]. As given in Figure 3a, the BE observed at 852.5 and $869.9 \mathrm{eV}$ were ascribed to the Ni $2 \mathrm{p}_{3 / 2}$ and $\mathrm{Ni} 2 \mathrm{p}_{1 / 2}$ of metallic $\mathrm{Ni}$, respectively. The oxidized Ni centered at 858.1 and $876.5 \mathrm{eV}$ were detected, which might likely attribute to the partial oxidation of $\mathrm{Ni}$ during the sample treatment route for the XPS measurements, as revealed before [56-58]. The BE of 71.4 and $74.6 \mathrm{eV}$ in Figure 3b corresponded to the $\mathrm{Pt} 4 \mathrm{f}_{7 / 2}$ and $\mathrm{Pt} 4 \mathrm{f}_{5 / 2}$ of metallic $\mathrm{Pt}$. In addition, there was a positive shift toward $0.1 \mathrm{eV}$ for the $\mathrm{BE}$ of $\mathrm{Pt}$ in $\mathrm{Pt}_{0.5} \mathrm{Ni}_{0.5} / \mathrm{g}-\mathrm{C}_{3} \mathrm{~N}_{4}$ compared with that of pure $\mathrm{Pt}$, while a negative shift with $0.4 \mathrm{eV}$ could be observed for $\mathrm{Ni}$ in $\mathrm{Pt}_{0.5} \mathrm{Ni}_{0.5} / \mathrm{g}-\mathrm{C}_{3} \mathrm{~N}_{4}$ in comparison with that of pure $\mathrm{Ni}$, thereby confirming the formation of the PtNi alloy, which was in good agreement with those of alloys previously reported [56-61].

To further explore the morphology and microstructure of the $\mathrm{Pt}_{0.5} \mathrm{Ni}_{0.5} / \mathrm{g}-\mathrm{C}_{3} \mathrm{~N}_{4}$ catalyst, we conducted TEM, high-angle annular dark-field scanning transmission electron microscopy (HAADF-STEM), and energy-dispersive X-ray spectroscopic (EDS) measurements, as depicted in Figure $4 \mathrm{a}-\mathrm{i}$. The TEM images of $\mathrm{Ni} / \mathrm{g}-\mathrm{C}_{3} \mathrm{~N}_{4}$ revealed that almost all the nanoparticles were uniformly dispersed into the surface of $\mathrm{g}-\mathrm{C}_{3} \mathrm{~N}_{4}$ with an average size of $4.3 \mathrm{~nm}$ (Figure S3a,b). Furthermore, for Pt/g- $\mathrm{C}_{3} \mathrm{~N}_{4}$, there were many homogeneous distribution of nanoparticles with their size ranging from 3.6 to $6.0 \mathrm{~nm}$, as depicted in Figure S3d,e. However, TEM images revealed that the PtNi nanoparticles 
in $\mathrm{Pt}_{0.5} \mathrm{Ni}_{0.5} / \mathrm{g}-\mathrm{C}_{3} \mathrm{~N}_{4}$ catalyst had a uniform diameter distribution with a mean diameter of $3.2 \mathrm{~nm}$ and were homogeneously dispersed on the surface of $g-\mathrm{C}_{3} \mathrm{~N}_{4}$ (Figure $4 \mathrm{a}-\mathrm{c}$ ), which might be due to the alloy effect. Figure $4 \mathrm{~b}$ presents that the $\mathrm{d}$-spacing of the particle was $0.211 \mathrm{~nm}$, which differed from the (111) plane of $\mathrm{Pt}$ (0.227 nm; Figure S3f) and $\mathrm{Ni}\left(0.204 \mathrm{~nm}\right.$; Figure S3c), further revealing that $\mathrm{Pt}_{0.5} \mathrm{Ni}_{0.5}$ was in the form of the alloy state [54-56,58-61]. The energy dispersive X-ray (EDX) result (Figure S4) further verified the coexistence of $\mathrm{Pt}$ and $\mathrm{Ni}$ in the $\mathrm{Pt}_{0.5} \mathrm{Ni}_{0.5} / \mathrm{g}-\mathrm{C}_{3} \mathrm{~N}_{4}$. A representative high-angle annular dark-field scanning TEM (HAADF-STEM) image confirmed the homogeneous distribution of Pt and Ni elements on the $g-C_{3} N_{4}$ catalyst surface at the same position (Figure $4 \mathrm{~d}-\mathrm{i}$ ), which confirmed again the formation of a PtNi alloy.
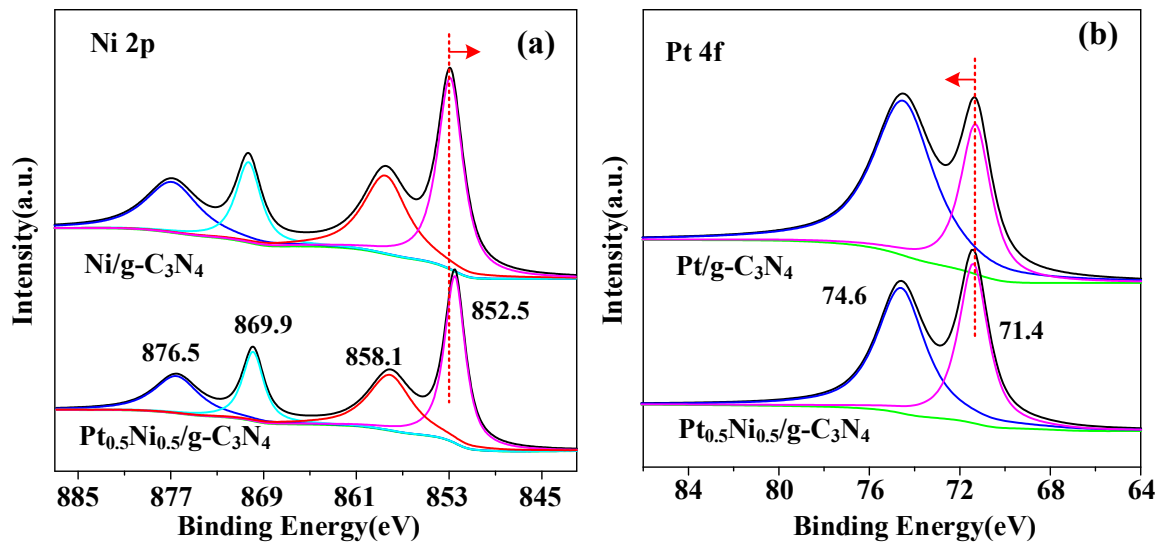

Figure 3. X-ray photoelectron spectroscopy (XPS) spectra for catalyst $\mathrm{Ni} / \mathrm{g}-\mathrm{C}_{3} \mathrm{~N}_{4}, \mathrm{Pt} / \mathrm{g}-\mathrm{C}_{3} \mathrm{~N}_{4}$, and $\mathrm{Pt}_{0.5} \mathrm{Ni}_{0.5} / \mathrm{g}-\mathrm{C}_{3} \mathrm{~N}_{4}$ showing (a) $\mathrm{Ni} 2 \mathrm{p}$ and (b) $\mathrm{Pt} 4 \mathrm{f}$.

(a)

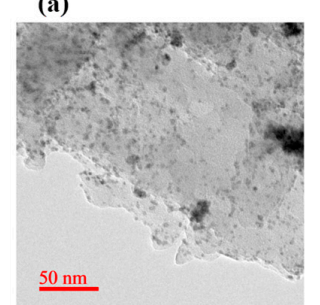

(d) (b)

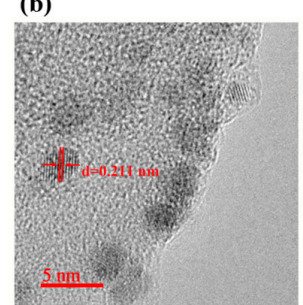

(e) (c)

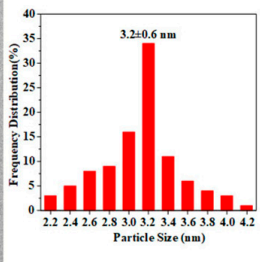

(f)

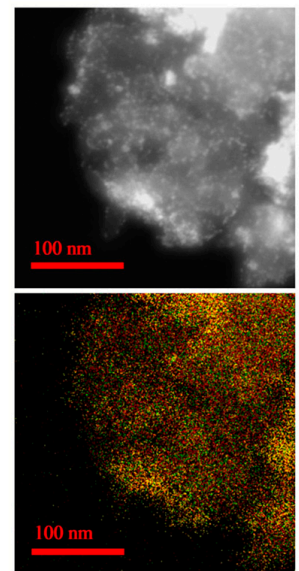

(g)

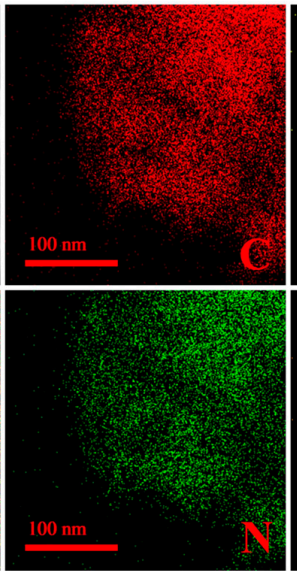

(h)

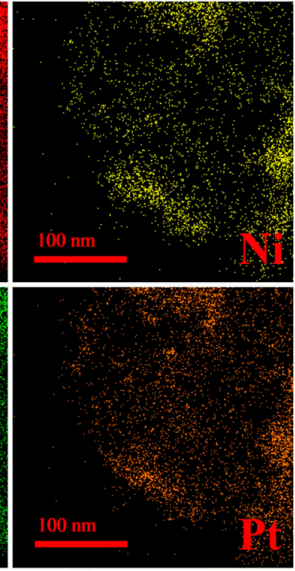

(i)

Figure 4. (a) TEM images of $\mathrm{Pt}_{0.5} \mathrm{Ni}_{0.5} / \mathrm{g}-\mathrm{C}_{3} \mathrm{~N}_{4}$, (b) amplified High Resolution Transmission Electron Microscopy (HRTEM) image of $\mathrm{Pt}_{0.5} \mathrm{Ni}_{0.5} / \mathrm{g}-\mathrm{C}_{3} \mathrm{~N}_{4}$, (c) particle size distribution of $\mathrm{Pt}_{0.5} \mathrm{Ni}_{0.5} \mathrm{NPs}_{\text {, }}$ (d) high-angle annular dark-field scanning TEM (HAADF-STEM) image, and (g) mix distribution of $\mathrm{C}, \mathrm{N}, \mathrm{Ni}$, and $\mathrm{Pt}$ of $\mathrm{Pt}_{0.5} \mathrm{Ni}_{0.5} / \mathrm{g}-\mathrm{C}_{3} \mathrm{~N}_{4},(\mathbf{e}, \mathbf{f}, \mathbf{h}, \mathbf{i}) \mathrm{C}, \mathrm{Ni}, \mathrm{N}$, and Pt elemental mapping images of $\mathrm{Pt}_{0.5} \mathrm{Ni}_{0.5} / \mathrm{g}-\mathrm{C}_{3} \mathrm{~N}_{4}$. 
Figure 5a presents the hydrogen release from $\mathrm{AB}$ catalyzed by $\mathrm{Pt}_{\mathrm{x}} \mathrm{Ni}_{1-\mathrm{x}} / \mathrm{g}-\mathrm{C}_{3} \mathrm{~N}_{4}$ catalyst with different components. Among all the $\mathrm{Pt}_{\mathrm{x}} \mathrm{Ni}_{1-\mathrm{x}} / \mathrm{g}-\mathrm{C}_{3} \mathrm{~N}_{4}$ conducted, $\mathrm{Pt}_{0.5} \mathrm{Ni}_{0.5} / \mathrm{g}-\mathrm{C}_{3} \mathrm{~N}_{4}$ revealed optimum catalytic performance towards the dehydrogenation of $\mathrm{AB}$ in comparison with that of another molar ratio of $\mathrm{Pt}_{\mathrm{x}} \mathrm{Ni}_{1-\mathrm{x}} / \mathrm{g}-\mathrm{C}_{3} \mathrm{~N}_{4}$. The hydrogen production from $\mathrm{AB}$ hydrolysis dehydrogenation over $\mathrm{Pt}_{0.5} \mathrm{Ni}_{0.5} / \mathrm{g}-\mathrm{C}_{3} \mathrm{~N}_{4}$ could be completed within only $1.5 \mathrm{~min}$, giving a TOF value of $250.8 \mathrm{~mol}_{\mathrm{H} 2} \mathrm{~min}^{-1}$ $\left(\mathrm{mol}_{\mathrm{Pt}}\right)^{-1}$ (Figure $5 \mathrm{~b}$ ), which was the highest as compared with other as-prepared PtNi alloy catalysts, as well higher than most reported Pt-based or other noble metal-based catalysts towards the hydrogen evolution of AB hydrolysis dehydrogenation as displayed in Table $1[38,40,62-68]$. The results showed that the platinum coupling with nickel could significantly improve the hydrolytic activity of $\mathrm{AB}$. The superior catalytic performance of the $\mathrm{Pt}_{0.5} \mathrm{Ni}_{0.5} / \mathrm{g}-\mathrm{C}_{3} \mathrm{~N}_{4}$ can be ascribed to the synergetic effect between Pt and Ni atoms as well as the enhanced interaction between PtNi NPs and g- $\mathrm{C}_{3} \mathrm{~N}_{4}$.
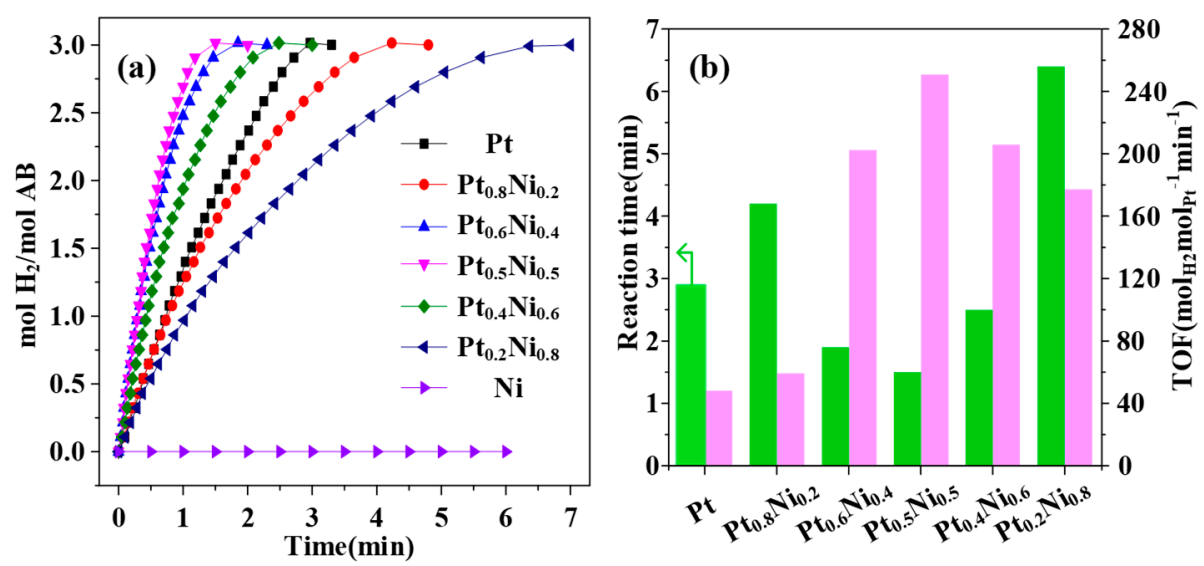

Figure 5. (a) Time plots of catalytic dehydrogenation of $\mathrm{AB}(4 \mathrm{mmol})$ by $\mathrm{PtNi} / \mathrm{g}-\mathrm{C}_{3} \mathrm{~N}_{4}$ catalyst with different ratios at $10{ }^{\circ} \mathrm{C}$; and (b) time needed to complete the reaction and turnover frequency (TOF) values (obtained based on the overall Pt moles) of the $\mathrm{PtNi} / \mathrm{g}-\mathrm{C}_{3} \mathrm{~N}_{4}$ catalysts.

Table 1. Catalytic activities and the activation energy of catalysts in the hydrolysis of AB.

\begin{tabular}{|c|c|c|c|}
\hline Catalysts & $\mathrm{TOF}\left(\mathrm{mol}_{\mathrm{H} 2} \mathrm{~min}^{-1} \mathrm{~mol}^{-1} \mathrm{M}\right) \mathrm{M}=\mathrm{Pt}, \mathrm{Ru}, \mathrm{Ag}$ & $\mathrm{E}_{\mathrm{a}}\left(\mathrm{kJ} \mathrm{mol}^{-1}\right)$ & Refs. \\
\hline $\mathrm{Pt}_{0.5} \mathrm{Ni}_{0.5} / \mathrm{g}-\mathrm{C}_{3} \mathrm{~N}_{4}$ & 250.8 & 38.09 & This work \\
\hline $\mathrm{NP}-\mathrm{Pt}_{40} \mathrm{Co}_{60}$ composite & 131 & 38.8 & 40 \\
\hline $\mathrm{Pt} @ \mathrm{SiO}_{2}$ & 158 & 53.6 & 62 \\
\hline $\mathrm{PtRu}$ & 59.6 & 38.9 & 63 \\
\hline $\mathrm{RuCu}$ /graphene & 135 & 30.89 & 64 \\
\hline $\mathrm{Pt} / \mathrm{CeO}_{2} / \mathrm{RGO}$ & 48 & - & 65 \\
\hline $\operatorname{RuCo}(1: 1) / \gamma-\mathrm{Al}_{2} \mathrm{O}_{3}$ & 32.9 & 47 & 66 \\
\hline $\mathrm{Pt}_{0.65} \mathrm{Ni}_{0.35}$ & 44.3 & 39.0 & 67 \\
\hline hnp- $-\mathrm{Pt}_{35} \mathrm{Cu}_{65}$ & 108 & 40.5 & 38 \\
\hline Pd-Pt@PVP NPs & 125 & 51.7 & 68 \\
\hline
\end{tabular}

Given that $\mathrm{Pt}_{0.5} \mathrm{Ni}_{0.5} / \mathrm{g}_{-} \mathrm{C}_{3} \mathrm{~N}_{4}$ demonstrated the best catalytic performance towards the dehydrogenation of $\mathrm{AB}$ in this work, $\mathrm{Pt}_{0.5} \mathrm{Ni}_{0.5} / g-\mathrm{C}_{3} \mathrm{~N}_{4}$, as the representative, was selected to further explore its dehydrogenation kinetics. As illustrated in Figure 6a, the catalyst concentrations-dependent test of $\mathrm{Pt}_{0.5} \mathrm{Ni}_{0.5} \mathrm{NPs}$ was investigated at $10^{\circ} \mathrm{C}$ by modifying the catalyst concentration ranging from 6.25 to $25 \mathrm{mM}$. The hydrogen generation rate demonstrated an obvious upward tendency with the increasing of catalyst concentrations. The relation between logarithmic plots of dehydrogenation rate and catalyst concentrations is illustrated in Figure $6 \mathrm{~b}$. The slope of straight line was estimated to be 1.08 , implying that the dehydrogenation reaction was first-order in terms of the catalyst concentration. Furthermore, to explore the influence of $A B$ concentration on the dehydrogenation of $A B$, a series of experiments with different concentrations of $\mathrm{AB}$ were performed, where the $\mathrm{AB}$ concentrations were 
modulated from 250 to $1000 \mathrm{mM}$, as shown in Figure $6 \mathrm{a}$, and $\mathrm{Pt}_{0.5} \mathrm{Ni}_{0.5} / \mathrm{g}-\mathrm{C}_{3} \mathrm{~N}_{4} \mathrm{NPs}$ was kept at $0.100 \mathrm{~g}$. Figure $7 \mathrm{a}$ shows corresponding hydrogen amount versus time. As the concentration of $\mathrm{AB}$ increased, the dehydrogenation reaction time increased clearly from 0.8 to $1.5 \mathrm{~min}$. Figure $7 \mathrm{~b}$ displays logarithmic plots of dehydrogenation rate versus $A B$ concentrations, where the line slope was 0.05 , suggesting that the dehydrogenation reaction of $\mathrm{AB}$ presents zero-order regarding the catalyst concentrations.
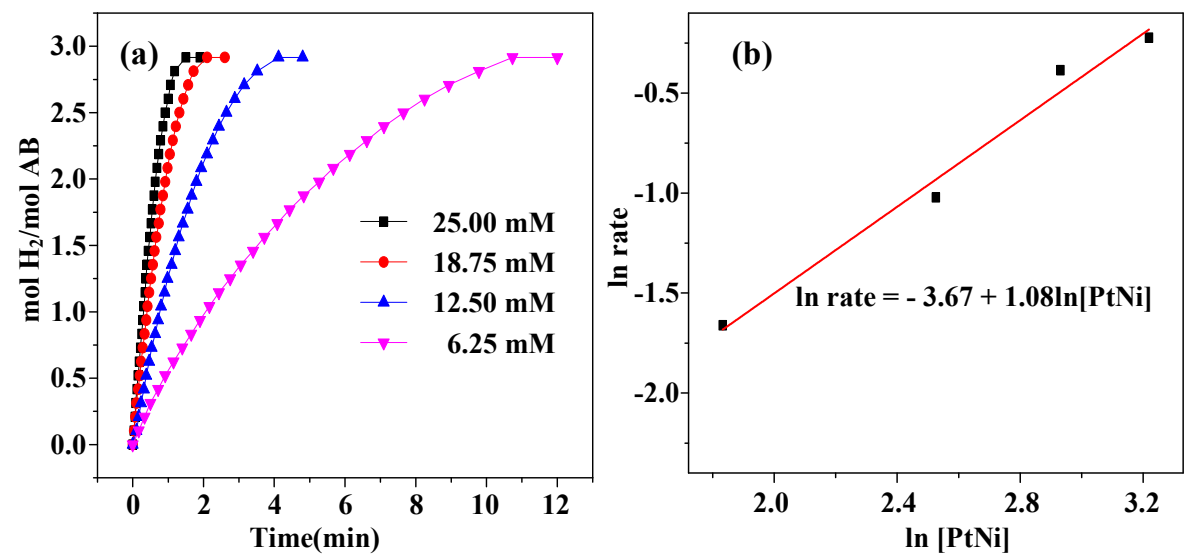

Figure 6. (a) Plots of moles of $\mathrm{H}_{2}$ per mole of $A B$ versus time for the hydrolysis of $A B(4 \mathrm{mmol})$ in the presence of $\mathrm{Pt}_{0.5} \mathrm{Ni}_{0.5} / \mathrm{g}-\mathrm{C}_{3} \mathrm{~N}_{4}$ at different catalyst concentrations at $10{ }^{\circ} \mathrm{C}$, and $(\mathbf{b})$ the logarithmic plot of hydrogen evolution rate versus PtNi concentrations.
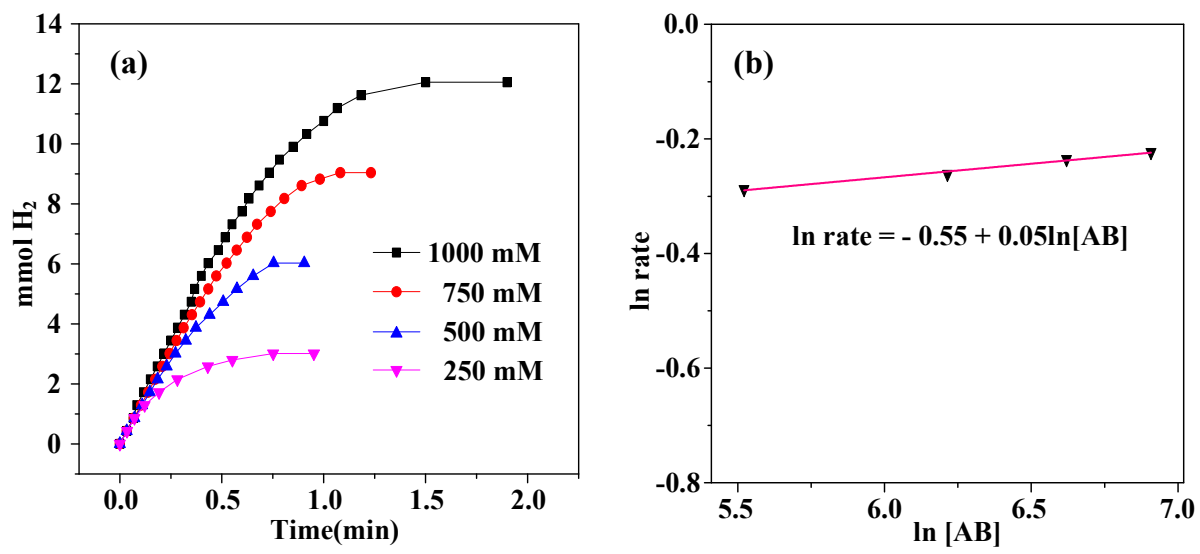

Figure 7. (a) Plot of $\mathrm{H}_{2}$ mole versus time for hydrogen generation from $\mathrm{AB}$ hydrolysis catalyzed by $\mathrm{Pt}_{0.5} \mathrm{Ni}_{0.5} / \mathrm{g}-\mathrm{C}_{3} \mathrm{~N}_{4}$ catalyst at different $\mathrm{AB}$ concentrations $\left(\left[\mathrm{Pt}_{0.5} \mathrm{Ni}_{0.5} / \mathrm{g}-\mathrm{C}_{3} \mathrm{~N}_{4}\right]=0.100 \mathrm{~g}, \mathrm{~T}=10{ }^{\circ} \mathrm{C}\right)$, and (b) the logarithmic plot of hydrogen evolution rate versus $\mathrm{AB}$ concentrations.

To explore the influence of temperature, the $\mathrm{AB}$ concentration was maintained at $1000 \mathrm{mM}$ and the $\mathrm{Pt}_{0.5} \mathrm{Ni}_{0.5} / \mathrm{g}-\mathrm{C}_{3} \mathrm{~N}_{4}$ was kept at $0.100 \mathrm{~g}$. Plot of the molar ratio of $\mathrm{H}_{2} / \mathrm{AB}$ versus time for hydrogen evolution from $\mathrm{AB}$ catalyzed by $\mathrm{Pt}_{0.5} \mathrm{Ni}_{0.5} / \mathrm{g}-\mathrm{C}_{3} \mathrm{~N}_{4}$ catalyst at different temperatures are presented in Figure $8 \mathrm{a}$. As the reaction temperature changed from -5 to $10^{\circ} \mathrm{C}$, the dehydrogenation rate significantly increased. According to the slop of the straight line in Figure 8b, the activation energy was estimated to be $38.09 \mathrm{~kJ} / \mathrm{mol}$, which was lower than most of the reported $E_{a}$ values of many different Pt-based and some other catalysts [62-68].

Combining the XRD, FT-IR, XPS, and TEM, a possible mechanism for the hydrogen evolution from ammonia borane catalyzed by $\mathrm{Pt}_{0.5} \mathrm{Ni}_{0.5} / \mathrm{g}-\mathrm{C}_{3} \mathrm{~N}_{4}$ can be proposed. The obtained results endow persuasive and obvious evidence regarding the synergistic effects between $\mathrm{Pt}$ and $\mathrm{Ni}$ in the $\mathrm{Pt}_{0.5} \mathrm{Ni}_{0.5}$ NPs and the synergistic electronic effects between $\mathrm{Pt}_{0.5} \mathrm{Ni}_{0.5}$ nanoparticles and $\mathrm{g}-\mathrm{C}_{3} \mathrm{~N}_{4}$, which could efficiently activate the $\mathrm{B}-\mathrm{N}$ bonds in $\mathrm{AB}$, thereby lowering the reaction energy barrier and prompting hydrogen evolution, as verified by Table S1. As shown in Scheme 2, firstly, both $\mathrm{H}_{2} \mathrm{O}$ and AB 
were adsorbed on the surface of the catalyst, and then, the $\mathrm{B}-\mathrm{H}$ bond of $\mathrm{AB}$ was broken to form $\mathrm{H}_{3} \mathrm{NBH}_{2}-\mathrm{OH}$ by attacking $\mathrm{BH}_{3}{ }^{*}$ group in $\mathrm{H}_{3} \mathrm{NBH}_{3}$ using $\mathrm{OH}^{*}$, the $\mathrm{OH}^{*}$ further attacked other $\mathrm{B}-\mathrm{H}$ to dissociate hydrogen atoms. At last, the dissociated hydrogen atoms in the surface of the catalysts could combine to release hydrogen gas [69-72]. In addition, the active energy for the dehydrogenation catalyzed by $\mathrm{Pt}_{0.5} \mathrm{Ni}_{0.5} / \mathrm{g}-\mathrm{C}_{3} \mathrm{~N}_{4}$ was calculated to as low as $38.09 \mathrm{~kJ} \mathrm{~mol}{ }^{-1}$ and its kinetics were also obviously improved.
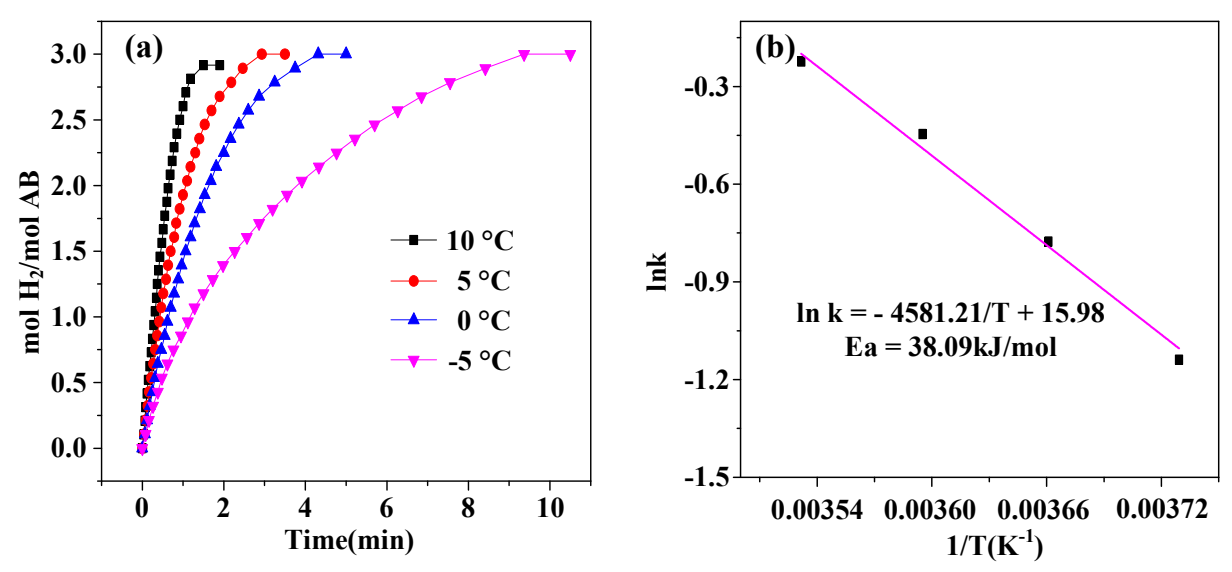

Figure 8. (a) Plot of equivalent $\mathrm{H}_{2}$ per mole of $\mathrm{AB}$ versus time for hydrogen generation from $\mathrm{AB}$ hydrolysis catalyzed by $\mathrm{Pt}_{0.5} \mathrm{Ni}_{0.5} / \mathrm{g}-\mathrm{C}_{3} \mathrm{~N}_{4}$ catalyst at different temperatures $\left(\left[\mathrm{Pt}_{0.5} \mathrm{Ni}_{0.5} / \mathrm{g}-\mathrm{C}_{3} \mathrm{~N}_{4}\right]=\right.$ $0.100 \mathrm{~g},[\mathrm{AB}]=4 \mathrm{mM})$, and (b) Arrhenius plot of ln k vs. $(1 / \mathrm{T})$.

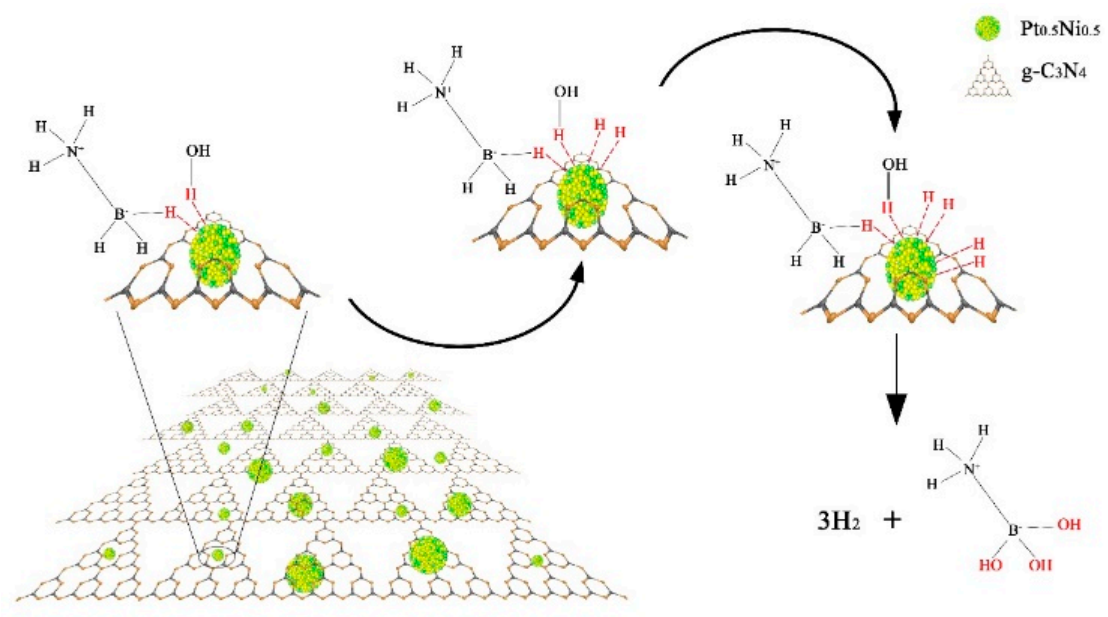

Scheme 2. Possible mechanism of hydrogen evolution from $\mathrm{NH}_{3} \mathrm{BH}_{3}$ in aqueous solution over $\mathrm{Pt}_{0.5} \mathrm{Ni}_{0.5} / \mathrm{g}-\mathrm{C}_{3} \mathrm{~N}_{4}$.

The stability, as a significant issue for the large-scale application of one catalyst, of the $\mathrm{Pt}_{0.5} \mathrm{Ni}_{0.5} / \mathrm{g}-\mathrm{C}_{3} \mathrm{~N}_{4}$ in the hydrolytic dehydrogenation of $\mathrm{AB}$ was studied and displayed in Figure $9 \mathrm{a}$. However, after 10 successive cycles, the hydrolysis of $\mathrm{AB}$ can also be completed within $3 \mathrm{~min}$, generating a TOF value of $136.8 \mathrm{~mol}_{\mathrm{H} 2} \mathrm{~min}^{-1}\left(\mathrm{~mol}_{\mathrm{Pt}}\right)^{-1}$, which is only $55 \%$ of its initial catalytic activity. To further explore the reason for the decreased dehydrogenation performance, the morphology of $\mathrm{Pt}_{0.5} \mathrm{Ni}_{0.5} / \mathrm{g}-\mathrm{C}_{3} \mathrm{~N}_{4}$ after the cycle test was characterized by TEM, as presented in Figure $9 \mathrm{~b}$. The slight aggregation can be observed, which may be attributed to the activity decay of $\mathrm{Pt}_{0.5} \mathrm{Ni}_{0.5} / \mathrm{g}_{-} \mathrm{C}_{3} \mathrm{~N}_{4}$. 


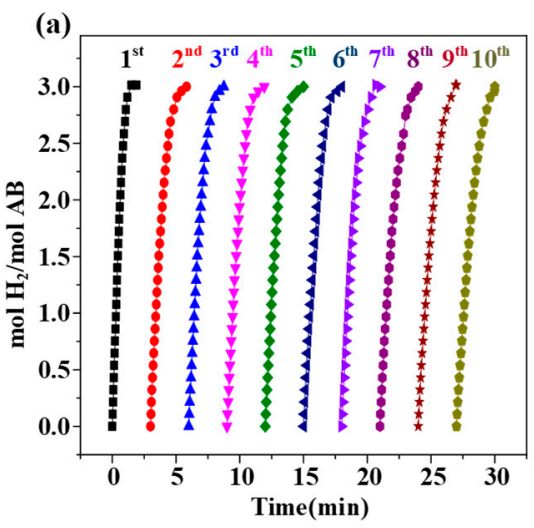

(b)

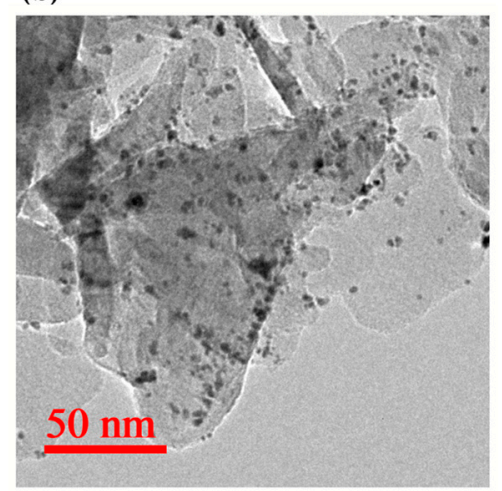

Figure 9. (a) Durability test of $\mathrm{Pt}_{0.5} \mathrm{Ni}_{0.5} / \mathrm{g}-\mathrm{C}_{3} \mathrm{~N}_{4}$ in ten runs for hydrogen generation from hydrolysis of aqueous $\mathrm{AB}$ solution, and (b) TEM image of $\mathrm{Pt}_{0.5} \mathrm{Ni}_{0.5} / \mathrm{g}-\mathrm{C}_{3} \mathrm{~N}_{4}$ after ten cycles.

\section{Materials and Methods}

\subsection{Materials and Chemicals}

Ammonia borane $\left(\mathrm{NH}_{3} \mathrm{BH}_{3}, \mathrm{AB}, \geq 90 \%\right.$, ) and melamine $\left(\mathrm{C}_{3} \mathrm{H}_{6} \mathrm{~N}_{6}, \geq 99 \%\right)$ were obtained from Aldrich (Shanghai, China). Chloroplatinic acid $\left(\mathrm{H}_{2} \mathrm{PtCl}_{6}\right)$ was supplied by Nanjing Chemical Reagent Co., Ltd. (Nanjing, China). Nickel(II) chloride hexahydrate $\left(\mathrm{NiCl}_{2} \cdot 6 \mathrm{H}_{2} \mathrm{O}, \mathrm{AR}\right)$, sodium hydroxide $(\mathrm{NaOH}, \geq 96.0 \%)$, and sodium borohydride $\left(\mathrm{NaBH}_{4}, \geq 98 \%\right)$ were purchased from Sinopharm Chemical Reagent Co., Ltd. (Shanghai, China). All chemicals were purchased and used without further treatment.

\subsection{Synthesis of $g-C_{3} N_{4}$}

Pure $\mathrm{g}-\mathrm{C}_{3} \mathrm{~N}_{4}$ was prepared by the direct pyrolysis of melamine, as reported by previous literatures [51,52]. Specifically, $2.00 \mathrm{~g}$ of melamine, placed into an alumina crucible with a cover, was annealed at $520^{\circ} \mathrm{C}$ in a muffle furnace for $2 \mathrm{~h}$ at a ramp rate of $3{ }^{\circ} \mathrm{C} / \mathrm{min}$. After cooling to room temperature naturally, the resulting yellow-colored material was $g-\mathrm{C}_{3} \mathrm{~N}_{4}$.

\subsection{Synthesis of PtNi/g- $\mathrm{C}_{3} \mathrm{~N}_{4}$}

$\mathrm{PtNi} / \mathrm{g}-\mathrm{C}_{3} \mathrm{~N}_{4}$ was fabricated via a simple and facile impregnation and chemical reduction method. In a typical procedure, for $\mathrm{Pt}_{0.5} \mathrm{Ni}_{0.5} / \mathrm{g}-\mathrm{C}_{3} \mathrm{~N}_{4}, 200 \mathrm{mg}$ of g- $\mathrm{C}_{3} \mathrm{~N}_{4}$ and $0.4 \mathrm{mmol}$ of metal precursors $\left(0.2 \mathrm{mmol}\right.$ of $\mathrm{H}_{2} \mathrm{PtCl}_{6}$ and $0.2 \mathrm{mmol}$ of $\mathrm{NiCl}_{2}$ ) were firstly mixed under ultrasonic for $30 \mathrm{~min}$, and then the mixture was continuously stirred for $24 \mathrm{~h}$ at room temperature. After that, a mixture solution containing $0.08 \mathrm{~g}$ of $\mathrm{NaBH}_{4}$ was added the above-mentioned solution at $-3^{\circ} \mathrm{C}$, and then stirring for $5 \mathrm{~h}$. Finally, the resulting mixture was centrifuged and dried at $80^{\circ} \mathrm{C}$ in a vacuum oven. The obtained powder was denoted as $\mathrm{Pt}_{0.5} \mathrm{Ni}_{0.5} / \mathrm{g}-\mathrm{C}_{3} \mathrm{~N}_{4}$. The g- $\mathrm{C}_{3} \mathrm{~N}_{4}$ supported $\mathrm{Pt} / \mathrm{Ni}$ with other molar ratios could be labeled as $\mathrm{Pt}_{\mathrm{x}} \mathrm{Ni}_{1-\mathrm{x}} / \mathrm{g}-\mathrm{C}_{3} \mathrm{~N}_{4}(\mathrm{x}=0,0.2,0.4,0.6,0.8$, and 1$)$.

\subsection{Characterization}

The crystal structure of the catalysts was recorded at a scanning rate of $4{ }^{\circ} \mathrm{min}^{-1}$ using a X-ray diffraction (XRD, Bruker, Berlin, Germany) D8-Advance, Cu Ka radiation source $(\lambda=0.154178 \mathrm{~nm})$ ). The Fourier transformed infrared spectra (FTIR) was investigated by a Tensor 27 spectrometer (Bruker, Berlin, Germany). The metal composition of the catalysts was conducted by employing inductively coupled plasma-atomic emission spectrometer (ICP-AES, Thermo iCAP6300, Washington, USA). The specific surface area was measured using Micromeritics ASAP2020 (Washington, USA) according to adsorption/desorption nitrogen isotherms. The electronic states of the surface of the as-obtained catalyst were measured by X-ray photoelectron spectroscopy (XPS, Thermo scientific Escalab 250Xi, Washington, USA). The morphologies and sizes of the catalysts were obtained using a transmission 
electron microscope (TEM, JEOL JEM 2100F, Freising, Germany) equipped with an energy dispersive X-ray detector (EDX, Freising, Germany) at a working voltage of $200 \mathrm{kV}$. The composition of the generated gas was evaluated through a Hiden QIC-20 quadruple mass spectrometer (Warrington, UK) using Ar as carrying gas.

\subsection{Catalytic Activity Measurement}

In a typical experiment, $0.1 \mathrm{~g}$ of the as-obtained $\mathrm{PtNi} / \mathrm{g}-\mathrm{C}_{3} \mathrm{~N}_{4}$ was dispersed into $2 \mathrm{~mL}$ water in a two-necked round-bottom flask. A solution containing $2 \mathrm{~mL}$ of $\mathrm{AB}(2 \mathrm{M})$ was injected through one neck with a syringe under stirring, and the other was connected with a gas burette to estimate the volume of gas. Upon the injection of $\mathrm{AB}$ aqueous solution, the amount of $\mathrm{H}_{2}$ production was estimated via water-displacement approach by measuring the volume of drained water. The reaction time was recorded as the first bubble appeared. The reaction was over when there was no gas released. The reaction was carried out under designed temperature, controlling by cryogenic bath. The turnover frequency (TOF, $\mathrm{mol}_{\mathrm{H} 2} \mathrm{~mol}_{\mathrm{Pt}}{ }^{-1} \mathrm{~min}^{-1}$ ) was calculated according to the linear relationship between volume and time in $\mathrm{AB}$ hydrolysis.

In order to explore the influence of catalysts concentration, $A B$ concentration over the dehydrogenation of $\mathrm{AB}, \mathrm{AB}$ hydrolysis for the $\mathrm{Pt}_{0.5} \mathrm{Ni}_{0.5} / \mathrm{g}-\mathrm{C}_{3} \mathrm{~N}_{4}$ was evaluated in the same way as described above, except that the parameters, such as catalysts concentration, $\mathrm{AB}$ concentration, were changed, respectively. In addition, to acquire the activation energy $\left(E_{a}\right)$ value of the hydrogen production of $\mathrm{AB}$ over $\mathrm{Pt}_{0.5} \mathrm{Ni}_{0.5} / \mathrm{g}-\mathrm{C}_{3} \mathrm{~N}_{4}$ catalyst, the hydrolysis of $\mathrm{AB}$ was conducted at a series of temperatures including $-5{ }^{\circ} \mathrm{C}, 0{ }^{\circ} \mathrm{C}, 5^{\circ} \mathrm{C}$, and $10{ }^{\circ} \mathrm{C}$.

\subsection{Stability Tests}

The catalyst was recovered by centrifugation, washed with ethanol and water, and dried in an oven after the completion of the dehydrogenation reaction. Then the recovered catalyst was set into a two-necked round-bottom flask according to the above-mentioned dehydrogenation procedure for stability tests. A similar operation was repeated ten times.

\section{Conclusions}

In summary, we reported a simple and facile impregnation and chemical reduction approach to synthesize PtNi/g- $\mathrm{C}_{3} \mathrm{~N}_{4}$ nanoparticles as a catalyst for boosting the hydrogen generation of $\mathrm{AB}$. Among the $\mathrm{Pt}_{\mathrm{x}} \mathrm{Ni}_{1-\mathrm{x}} / \mathrm{g}-\mathrm{C}_{3} \mathrm{~N}_{4}$ catalysts, the resultant $\mathrm{Pt}_{0.5} \mathrm{Ni}_{0.5} / \mathrm{g}-\mathrm{C}_{3} \mathrm{~N}_{4}$ catalyst demonstrated outstanding performance, including $100 \%$ conversion, $100 \% \mathrm{H}_{2}$ selectivity, yielding the extraordinary initial total turnover frequency (TOF) of $250.8 \mathrm{~mol}_{\mathrm{H} 2} \mathrm{~min}^{-1}\left(\mathrm{~mol}_{\mathrm{Pt}}\right)^{-1}$ for hydrogen production from $\mathrm{AB}$ at $10{ }^{\circ} \mathrm{C}$, a relatively low activation energy of $38.09 \mathrm{~kJ} \mathrm{~mol}^{-1}$, and a remarkable reusability (at least 10 times), which outperformed most of the noble metal heterogeneous catalysts. This notably improved activity was attributed to the charge interaction between PtNi NPs and g- $\mathrm{C}_{3} \mathrm{~N}_{4}$ support. Especially, the nitrogen-containing functional groups on $\mathrm{g}-\mathrm{C}_{3} \mathrm{~N}_{4}$, serving as the anchoring sites for PtNi NPs, might be beneficial for forming a uniform distribution and decreasing the particle size for the NPs. Moreover, the fabrication of g- $\mathrm{C}_{3} \mathrm{~N}_{4}$-based catalysts might prompt the utilization of $\mathrm{g}-\mathrm{C}_{3} \mathrm{~N}_{4}$ in energy fields.

Supplementary Materials: The following are available online at http://www.mdpi.com/2073-4344/9/12/1009/s1, Figure S1: $\mathrm{N}_{2}$ adsorption-desorption isotherms of $\mathrm{Pt}_{0.5} \mathrm{Ni}_{0.5} / \mathrm{g}-\mathrm{C}_{3} \mathrm{~N}_{4}$, Figure S2: XPS spectra for $\mathrm{Pt}_{0.5} \mathrm{Ni}_{0.5} / \mathrm{g}-\mathrm{C}_{3} \mathrm{~N}_{4}$ showing C 1s, N 1s, Figure S3: (a) TEM images of Ni/g- $\mathrm{C}_{3} \mathrm{~N}_{4}$, (b) amplified HRTEM image of $\mathrm{Ni} / \mathrm{g}-\mathrm{C}_{3} \mathrm{~N}_{4}$, (c) Particle size distribution of Ni/g- $\mathrm{C}_{3} \mathrm{~N}_{4}$, (d) TEM images of Pt/g- $\mathrm{C}_{3} \mathrm{~N}_{4}$, (e) amplified HRTEM image of Pt/g- $\mathrm{C}_{3} \mathrm{~N}_{4}$, (f) Particle size distribution of $\mathrm{Pt} / \mathrm{g}-\mathrm{C}_{3} \mathrm{~N}_{4}$, Figure S4: SEM-energy-dispersive X-ray spectroscopic (EDS) spectrum of $\mathrm{Pt}_{0.5} \mathrm{Ni}_{0.5} / \mathrm{g}-\mathrm{C}_{3} \mathrm{~N}_{4}$, Table S1: ICP-AES results of $\mathrm{PtNi} / \mathrm{g}-\mathrm{C}_{3} \mathrm{~N}_{4}$ catalysts.

Author Contributions: Data curation, M.Z.; Writing—original draft, X.X.; Investigation, Y.W.; Formal analysis, Y.A.; Funding acquisition, L.X.; Supervision, Writing-review and editing, C.W.

Funding: This work was financially supported by Anhui Provincial Natural Science Foundation (1608085QF156, 1908085QB68), the Natural Science Foundation of the Anhui Higher Education Institutions of China (KJ2019A0072), Foundation of Zhejiang Provincial Key Laboratory of Advanced Chemical Engineering Manufacture Technology 
(Grant No. ZJKL-ACEMT-1802), China Postdoctoral Science Foundation (2019M662060), Research Fund for Young Teachers of Anhui University of Technology (QZ201610) and National Natural Science Foundation of China (21376005).

Conflicts of Interest: The authors declare no conflict of interest.

\section{References}

1. Graetz, J. New approaches to hydrogen storage. Chem. Soc. Rev. 2009, 38, 73-82. [CrossRef] [PubMed]

2. Yu, X.B.; Tang, Z.W.; Sun, D.L.; Ouyang, L.Z.; Zhu, M. Recent advances and remaining challenges of nanostructured materials for hydrogen storage applications. Prog. Mater. Sci. 2017, 88, 1-48. [CrossRef]

3. He, T.; Pachfule, P.; Wu, H.; Xu, Q.; Chen, P. Hydrogen carriers. Nat. Rev. Mater. 2016, 1, 16059. [CrossRef]

4. Liu, T.; Wang, Q.T.; Yuan, J.Z.; Zhao, X.; Gao, G.H. Highly Dispersed Bimetallic Nanoparticles Supported on Titanium Carbides for Remarkable Hydrogen Release from Hydrous Hydrazine. ChemCatChem 2018, 10, 2200-2204. [CrossRef]

5. Yadav, M.; Xu, Q. Liquid-phase chemical hydrogen storage materials. Energy Environ. Sci. 2012, 5, 9698-9725. [CrossRef]

6. Schlapbach, L.; Züttel, A. Hydrogen-storage materials for mobile applications. Mater. Sustain. Energy 2011, 265-270.

7. Yao, F.; Li, X.; Wan, C.; Xu, L.X.; An, Y.; Ye, M.F.; Lei, Z. Highly efficient hydrogen release from formic acid using a graphitic carbon nitride-supported AgPd nanoparticle catalyst. Appl. Surf. Sci. 2017, 426, 605-611. [CrossRef]

8. Staubitz, A.; Robertson, A.P.M.; Manners, I. Ammonia-Borane and related compounds as dihydrogen sources. Chem. Rev. 2010, 110, 4079-4124. [CrossRef]

9. Zhou, Y.-H.; Wang, S.Q.; Zhang, Z.Y.; Williams, N.; Cheng, Y.; Gu, J. Hollow Nickel-Cobalt Layered Double Hydroxide Supported Palladium Catalysts with Superior Hydrogen Evolution Activity for Hydrolysis of Ammonia Borane. ChemCatChem 2018, 10, 3206-3213. [CrossRef]

10. Huang, X.Y.; Wang, A.J.; Zhang, L.; Fang, K.M.; Wu, L.J.; Feng, J.J. Melamine-assisted solvothermal synthesis of PtNi nanodentrites as highly efficient and durable electrocatalyst for hydrogen evolution reaction. J. Colloid Interface Sci. 2018, 531, 578-584. [CrossRef]

11. Wan, C.; Yao, F.; Li, X.; Hu, K.; Ye, M.F.; Xu, L.X.; An, Y. Bimetallic AgPd Nanoparticles Immobilized on Amine-Functionalized SBA-15 as Efficient Catalysts for Hydrogen Generation from Formic Acid. ChemistrySelect 2016, 1, 6907-6913. [CrossRef]

12. Chen, J.M.; Lu, Z.H.; Yao, Q.L.; Feng, G.; Luo, Y. Complete dehydrogenation of $\mathrm{N}_{2} \mathrm{H}_{4} \mathrm{BH}_{3}$ with $\mathrm{Ni}^{-} \mathrm{MCr}_{2} \mathrm{O}_{3}$ $(\mathrm{M}=\mathrm{Pt}$, Rh, and Ir) hybrid nanoparticles. J. Mater. Chem. A 2018, 6, 20746-20752. [CrossRef]

13. Zhang, L.T.; Cai, Z.L.; Yao, Z.D.; Ji, L.; Sun, Z.; Yan, N.H.; Zhang, B.Y.; Xiao, B.B.; Du, J.; Zhu, X.Q.; et al. A striking catalytic effect of facile synthesized $\mathrm{ZrMn} 2$ nanoparticles on the de/rehydrogenation properties of MgH2. J. Mater. Chem. A 2019, 7, 5626-5634. [CrossRef]

14. Akbayrak, S.; Özçifçi, Z.; Tabak, A. Regular Article Noble metal nanoparticles supported on activated carbon: Highly recyclable catalysts in hydrogen generation from the hydrolysis of ammonia borane. J. Colloid Interface Sci. 2019, 546, 324-332. [CrossRef] [PubMed]

15. Qu, X.P.; Jiang, R.; Li, Q.; Zeng, F.N.; Zheng, X.; Xu, Z.M.; Chen, C.H.; Peng, J. The hydrolysis of ammonia borane catalyzed by NiCoP/OPC-300 nanocatalysts: High selectivity and efficiency, and mechanism. Green Chem. 2019, 21, 850-860. [CrossRef]

16. Li, J.; Li, F.; Liao, J.; Liu, Q.; Li, H. $\mathrm{Cu}_{0.4} \mathrm{Co}_{0.6} \mathrm{MoO}_{4}$ Nanorods Supported on Graphitic Carbon Nitride as a Highly Active Catalyst for the Hydrolytic Dehydrogenation of Ammonia Borane. Catalysts 2019, 9, 714. [CrossRef]

17. Torres, D.A.; Garcia, M.N.; Mori, K.; Kuwahara, Y.; Yamashita, H. Nitrogen-doped carbon materials as a promising platform toward the efficient catalysis for hydrogen generation. Appl. Catal. A Gen. 2019, 571, 25-41. [CrossRef]

18. Bandaru, S.; English, N.J.; Phillips, A.D.; MacElroy, J.M.D. Exploring Promising Catalysts for Chemical Hydrogen Storage in Ammonia Borane: A Density Functional Theory Study. Catalysts 2017, 7, 140. [CrossRef] 
19. Wei, Z.H.; Liu, Y.; Peng, Z.K.; Song, H.Q.; Liu, Z.Y.; Liu, B.Z.; Li, B.J.; Yang, B.; Lu, S.Y. Cobalt-Ruthenium Nanoalloys Parceled in Porous Nitrogen-Doped Graphene as Highly Efficient Difunctional Catalysts for Hydrogen Evolution Reaction and Hydrolysis of Ammonia Borane. ACS Sustain. Chem. Eng. 2019, 7, 7014-7023. [CrossRef]

20. Chen, W.Y.; Wang, Z.J.; Duan, X.Z.; Qian, G.; Chen, D.; Zhou, X.G. Structural and kinetic insights into $\mathrm{Pt} / \mathrm{CNT}$ catalysts during hydrogen generation from ammonia borane. Chem. Eng. Sci. 2018, 192, 1242-1251. [CrossRef]

21. Xu, C.L.; Wang, H.; Wang, Q.; Wang, Y.; Zhang, Y.; Fan, G.Y. Ruthenium coordinated with triphenylphosphine-hyper-crosslinked polymer: An efficient catalyst for hydrogen evolution reaction and hydrolysis of ammonia borane. Appl. Surf. Sci. 2019, 466, 193-201. [CrossRef]

22. Zhang, J.K.; Chen, W.Y.; Ge, H.B.; Chen, C.Q.; Yan, W.J.; Gao, Z.; Gan, J.; Zhang, B.Y.; Duan, X.Z.; Qin, Y. Synergistic effects in atomic-layer-deposited PtCox/CNTs catalysts enhancing hydrolytic dehydrogenation of ammonia borane. Appl. Catal. B 2018, 235, 256-263. [CrossRef]

23. Liu, Y.; Zhang, J.; Guan, H.J.; Zhao, Y.F.; Yang, J.H.; Zhang, B. Preparation of bimetallic Cu-Co nanocatalysts on poly (diallyldimethylammonium chloride) functionalized halloysite nanotubes for hydrolytic dehydrogenation of ammonia borane. Appl. Surf. Sci. 2018, 427, 106-113. [CrossRef]

24. Hou, C.C.; Li, Q.; Wang, C.J.; Peng, C.Y.; Chen, Q.Q.; Ye, H.F.; Fu, W.F.; Che, C.M.; López, N.; Chen, Y. Ternary Ni-Co-P nanoparticles as noble-metal-free catalysts to boost the hydrolytic dehydrogenation of ammonia-borane. Energy Environ. Sci. 2017, 10, 1770-1776. [CrossRef]

25. Zhao, W.; Wang, R.Y.; Wang, Y.; Feng, J.W.; Li, C.C.; Chen, G.Z. Effect of LDH composition on the catalytic activity of $\mathrm{Ru} / \mathrm{LDH}$ for the hydrolytic dehydrogenation of ammonia borane. Int. J. Hydrogen Energy 2019, 44, 14820-14830. [CrossRef]

26. Özhava, D.; Özkar, S. Nanoceria supported rhodium (0) nanoparticles as catalyst for hydrogen generation from methanolysis of ammonia borane. Appl. Catal. B 2018, 237, 1012-1020. [CrossRef]

27. Akbayrak, S.; Özkar, S. Ammonia borane as hydrogen storage materials. Int. J. Hydrogen Energy 2018, 43, 18592-18606. [CrossRef]

28. Wen, M.; Wu, Q.N.; Peng, J.; Wu, Q.S.; Wang, C.X. Fabrication of Pt-loaded NiCo nanochains with superior catalytic dehydrogenation activity. J. Colloid Interface Sci. 2014, 416, 220-226. [CrossRef]

29. Wan, C.; Cheng, D.G.; Chen, F.Q.; Zhan, X.L. Fabrication of $\mathrm{CeO}_{2}$ nanotube supported Pt catalyst encapsulated with silica for high and stable performance. Chem. Commun. 2015, 51, 9785-9788. [CrossRef]

30. Wang, S.; Zhang, D.; Ma, Y.Y.; Zhang, H.; Gao, J.; Nie, Y.T.; Sun, X.H. Aqueous solution synthesis of Pt-M $(\mathrm{M}=\mathrm{Fe}, \mathrm{Co}, \mathrm{Ni})$ bimetallic nanoparticles and their catalysis for the hydrolytic dehydrogenation of ammonia borane. ACS Appl. Mater. Interfaces 2014, 6, 12429-12435. [CrossRef]

31. Du, Y.S.; Su, J.; Luo, W.; Cheng, G.Z. Graphene-Supported Nickel-Platinum Nanoparticles as Efficient Catalyst for Hydrogen Generation from Hydrous Hydrazine at Room Temperature. ACS Appl. Mater. Interfaces 2015, 7, 1031-1034. [CrossRef] [PubMed]

32. Zhao, B.H.; Feng, K.; Wang, Y.; Lv, X.X.; Zheng, H.C.; Ma, Y.Y.; Yan, W.S.; Sun, X.H.; Zhong, J. Pt $t_{x} N_{10-x} O$ nanoparticles supported on $\mathrm{N}$-doped graphene oxide with a synergetic effect for highly efficient hydrolysis of ammonia borane. Catal. Sci. Technol. 2017, 7, 5135-5142. [CrossRef]

33. Xia, Y.; Ye, J.R.; Cheng, D.G.; Chen, F.Q.; Zhan, X.L. Identification of a flattened Pd-Ce oxide cluster as a highly efficient catalyst for low-temperature CO oxidation. Catal. Sci. Technol. 2018, 8, 5137-5147. [CrossRef]

34. Huang, X.Y.; Zhu, X.Y.; Zhang, X.F.; Zhang, L.; Feng, J.J.; Wang, A.J. Simple solvothermal synthesis of uniform Pt66Ni34 nanoflowers as advanced electrocatalyst to significantly boost the catalytic activity and durability of hydrogen evolution reaction. Electrochim. Acta 2018, 271, 397-405. [CrossRef]

35. Chen, X.L.; Zhang, H.X.; Huang, X.Y.; Feng, J.J.; Han, D.M.; Zhang, L.; Chen, J.R.; Wang, A.J. Facile solvothermal fabrication of Pt47Ni53 nanopolyhedrons for greatly boosting electrocatalytic performances for oxygen reduction and hydrogen evolution. J. Colloid Interface Sci. 2018, 525, 260-268. [CrossRef]

36. Karaca, T.; Sevim, M.; Metin, Ö. Facile Synthesis of Monodisperse Copper-Platinum Alloy Nanoparticles and Their Superb Catalysis in the Hydrolytic Dehydrogenation of Ammonia Borane and Hydrazine Borane. Chem CatChem 2017, 9, 4185-4190. [CrossRef]

37. Zhang, H.M.; Ke, D.D.; Cheng, L.N.; Feng, X.L.; Hou, X.W.; Wang, J.; Lia, Y.; Han, S.M. CoPt-Co hybrid supported on amino modified $\mathrm{SiO} 2$ nanospheres as a high performance catalyst for hydrogen generation from ammonia borane. Sci. Mater. 2019, 29, 1-9. [CrossRef] 
38. Zhou, Q.X.; Qi, L.; Yang, H.X.; Xu, C.X. Hierarchical nanoporous platinum-copper alloy nanoflowers as highly active catalysts for the hydrolytic dehydrogenation of ammonia borane. J. Colloid Interface Sci. 2018, 513, 258-265. [CrossRef]

39. Ge, Y.Z.; Ye, W.Y.; Shah, Z.H.; Lin, X.J.; Lu, R.W.; Zhang, S.F. PtNi/NiO Clusters Coated by Hollow Sillica: Novel Design for Highly Efficient Hydrogen Production from Ammonia-Borane. ACS Appl. Mater. Interfaces 2017, 9, 3749-3756. [CrossRef]

40. Zhou, Q.X.; Xu, C.X. Nanoporous $\mathrm{PtCo} / \mathrm{Co}_{3} \mathrm{O}_{4}$ composites with high catalytic activities toward hydrolytic dehydrogenation of ammonia borane. J. Colloid Interface Sci. 2017, 508, 542-550. [CrossRef]

41. Chen, W.Y.; Ji, J.; Feng, X.; Duan, X.Z.; Qian, G.; Li, P.; Zhou, X.G.; Chen, D.; Yuan, W.K. Mechanistic Insight into Size-Dependent Activity and Durability in Pt/CNT Catalyzed Hydrolytic Dehydrogenation of Ammonia Borane. J. Am. Chem. Soc. 2014, 136, 16736-16739. [CrossRef] [PubMed]

42. Kamegawa, T.; Nakaue, T. Complete hydrogen release from aqueous ammonia-borane over a platinum-loaded titanium dioxide photocatalyst. Chem. Commun. 2015, 51, 16802-16805. [CrossRef] [PubMed]

43. Zhu, M.Y.; Xu, L.X.; Du, L.; An, Y.; Wan, C. Palladium supported on carbon nanotubes as a high-performance catalyst for the dehydrogenation of dodecahydro-N-ethylcarbazole. Catalysts 2018, 8, 638. [CrossRef]

44. Ke, D.D.; Wang, J.; Zhang, H.M.; Li, Y.; Zhang, L.; Zhao, X.; Han, S.M. Fabrication of Pt-Co NPs supported on nanoporous graphene as high-efficient catalyst for hydrolytic dehydrogenation of ammonia borane. Int. J. Hydrogen Energy 2017, 42, 26617-26625. [CrossRef]

45. Wang, C.L.; Tuninetti, J.; Wang, Z.; Zhang, C.; Ciganda, R.; Salmon, L.; Moya, S.; Ruiz, J.; Astruc, D. Hydrolysis of Ammonia-Borane over Ni/ZIF-8 Nanocatalyst: High Efficiency, Mechanism, and Controlled Hydrogen Release. J. Am. Chem. Soc. 2017, 139, 11610-11615. [CrossRef] [PubMed]

46. Wang, W.; Lu, Z.H.; Luo, Y.; Zou, A.H.; Yao, Q.L.; Chen, X.S. Mesoporous Carbon Nitride Supported Pd and Pd-Ni Nanoparticles as Highly Efficient Catalyst for Catalytic Hydrolysis of $\mathrm{NH}_{3} \mathrm{BH}_{3}$. ChemCatChem 2018, 10, 1620-1626. [CrossRef]

47. Han, C.H.; Meng, P.; Waclawik, E.R.; Zhang, C.; Li, X.H.; Yang, H.Q.; Antonietti, M.; Xu, J.S. Palladium/Graphitic Carbon Nitride $\left(\mathrm{g}-\mathrm{C}_{3} \mathrm{~N}_{4}\right)$ Stabilized Emulsion Microreactor as a Store for Hydrogen from Ammonia Borane for Use in Alkene Hydrogenation. Angew. Chem. Int. Ed. 2018, 57, 14857-14861. [CrossRef]

48. Ong, W.J.; Tan, L.L.; Ng, Y.H.; Yong, S.T.; Chai, S.P. Graphitic Carbon Nitride $\left(\mathrm{g}-\mathrm{C}_{3} \mathrm{~N}_{4}\right)$-Based Photocatalysts for Artificial Photosynthesis and Environmental Remediation: Are We a Step Closer To Achieving Sustainability? Chem. Rev. 2016, 116, 7159-7329. [CrossRef]

49. Guo, L.T.; Cai, Y.Y.; Ge, J.M.; Zhang, Y.N.; Gong, L.H.; Li, X.H.; Wang, K.X.; Ren, Q.Z.; Su, J.; Chen, J.S. Multifunctional Au-Co@CN Nanocatalyst for Highly Efficient Hydrolysis of Ammonia Borane. ACS Catal. 2015, 5, 388-392. [CrossRef]

50. Lu, R.; Hu, M.; Xu, C.L.; Wang, Y.; Zhang, Y.; Xu, B.; Gao, D.J.; Bi, J.; Fan, G.Y. Hydrogen evolution from hydrolysis of ammonia borane catalyzed by Rh/g-C3N4 under mild conditions. Int. J. Hydrogen Energy 2018, 43, 7038-7045. [CrossRef]

51. Wang, X.C.; Blechert, S.; Antonietti, M. Polymeric Graphitic Carbon Nitride for Heterogeneous Photocatalysis. ACS Catal. 2012, 2, 1596-1606. [CrossRef]

52. Xu, L.X.; Liu, N.; Hong, B.; Cui, P.; Cheng, D.G.; Chen, F.Q.; An, Y.; Wan, C. Nickel-platinum nanoparticles immobilized on graphitic carbon nitride as highly efficient catalyst for hydrogen release from hydrous hydrazine. RSC Adv. 2016, 6, 31687-31691. [CrossRef]

53. Fu, F.Y.; Wang, C.L.; Wang, Q.; Martinez-Villacorta, A.M. Highly Selective and Sharp Volcano-type Synergistic $\mathrm{Ni}_{2} \mathrm{Pt} @ Z$ IF-8-Catalyzed Hydrogen Evolution from Ammonia Borane Hydrolysis. J. Am. Chem. Soc. 2018, 140, 10034-10042. [CrossRef] [PubMed]

54. Jiao, W.L.; Hu, X.P.; Ren, H.; Xu, P.F.; Yu, R.B.; Chen, J.; Xing, X.R. Magnetic Ni and Ni/Pt hollow nanospheres and their catalytic activities for hydrolysis of ammonia borane. J. Mater. Chem. A 2014, 2, 18171-18176. [CrossRef]

55. Li, Z.; He, T.; Matsumura, D.J.; Miao, S.; Wu, A.A.; Liu, L.; Wu, G.T.; Chen, P. Atomically Dispersed Pt on the Surface of Ni Particles: Synthesis and Catalytic Function in Hydrogen Generation from Aqueous Ammonia-Borane. ACS Catal. 2017, 7, 6762-6769. [CrossRef]

56. Wan, C.; Zhu, M.Y.; Du, L.; Xu, L.X.; Ye, M.F.; An, Y. Highly efficient aerobic oxidation of tetralin to alpha-tetralone over $\mathrm{MnO}_{x}-\mathrm{CoO}_{y} / \gamma-\mathrm{Al}_{2} \mathrm{O}_{3}$ catalysts. Catal. Commun. 2019, 125, 87-92. [CrossRef] 
57. Yao, Q.L.; Lu, Z.H.; Huang, W.; Chen, X.S.; Zhu, J. High Pt-like activity of the Ni-Mo/graphene catalyst for hydrogen evolution from hydrolysis of ammonia borane. J. Mater. Chem. A 2016, 4, 8579-8583. [CrossRef]

58. Wan, C.; Sun, L.; Xu, L.X.; Cheng, D.G.; Chen, F.Q.; Zhan, X.L.; Yang, Y.R. Novel NiPt alloy nanoparticle decorated 2D layered $g-C_{3} \mathrm{~N}_{4}$ nanosheets: A highly efficient catalyst for hydrogen generation from hydrous hydrazine. J. Mater. Chem. A 2019, 7, 8798-8804. [CrossRef]

59. Aranishi, K.; Singh, A.K.; Xu, Q. Dendrimer-encapsulated bimetallic Pt-Ni nanoparticles as highly efficient catalysts for hydrogen generation from chemical hydrogen storage materials. ChemCatChem 2013, 5, 2248-2252. [CrossRef]

60. Yang, X.J.; Cheng, F.Y.; Liang, J.; Tao, Z.L.; Chen, J. Carbon-supported $\mathrm{Ni}_{1-\mathrm{x}} @ \mathrm{Pt}_{\mathrm{x}}(\mathrm{x}=0.32,0.43,0.60,0.67$, and 0.80 ) core-shell nanoparticles as catalysts for hydrogen generation from hydrolysis of ammonia borane. Int. J. Hydrogen Energy 2011, 36, 1984-1990. [CrossRef]

61. Zhang, M.Y.; Liu, L.; Lu, S.; Xu, L.X.; An, Y.; Wan, C. Facile Fabrication of NiPt/CNTs as an Efficient Catalyst for Hydrogen Production from Hydrous Hydrazine. ChemistrySelect 2019, 4, 10494-10500. [CrossRef]

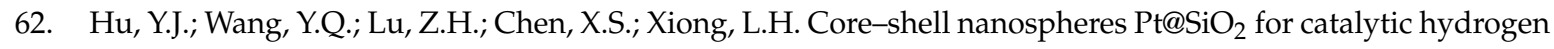
production. Appl. Surf. Sci. 2015, 341, 185-189. [CrossRef]

63. Zhou, Q.X.; Xu, C.X. Nanoporous PtRu alloys with unique catalytic activity toward hydrolytic dehydrogenation of ammonia borane. Chem. Asian J. 2016, 11, 705-712. [CrossRef] [PubMed]

64. Cao, N.; Hu, K.; Luo, W.; Cheng, G.Z. RuCu nanoparticles supported on graphene: A highly efficient catalyst for hydrolysis of ammonia borane. J. Alloy. Compd. 2014, 590, 241-246. [CrossRef]

65. Wang, X.; Liu, D.P.; Song, S.Y.; Zhang, H.J. Graphene oxide induced formation of $\mathrm{Pt}-\mathrm{CeO}_{2}$ hybrid nanoflowers with tunable $\mathrm{CeO}_{2}$ thickness for catalytic hydrolysis of ammonia borane. Chem. Eur. J. 2013, 19, 8082-8086. [CrossRef]

66. Rachiero, G.P.; Demirci, U.B.; Miele, P. Bimetallic RuCo and RuCu catalysts supported on $\gamma-\mathrm{Al} 2 \mathrm{O} 3$ a comparative study of their activity in hydrolysis of ammonia-borane. Int. J. Hydrogen Energy 2011, 36, 7051-7065. [CrossRef]

67. Yang, X.J.; Cheng, F.Y.; Liang, J.; Tao, Z.L.; Chen, J. Pt ${ }_{x} \mathrm{Ni}_{1-\mathrm{x}}$ nanoparticles as catalysts for hydrogen generation from hydrolysis of ammonia borane. Int. J. Hydrogen Energy 2009, 34, 8785-8791. [CrossRef]

68. Rakap, M. Poly(N-vinyl-2-pyrrolidone)-stabilized palladium-platinum nanoparticles-catalyzed hydrolysis of ammonia borane for hydrogen generation. J. Power Sources 2015, 276, 320-327. [CrossRef]

69. Kalidendi, S.B.; Sanyal, U.; Jagirdar, B.R. Nanostructured $\mathrm{Cu}$ and $\mathrm{Cu} @ \mathrm{Cu}_{2} \mathrm{O}$ core shell catalysts for hydrogen generation from ammonia-borane. Phys. Chem. Chem. Phys. 2008, 10, 5870-5874. [CrossRef]

70. Ma, H.; Na, C. Isokinetic Temperature and Size-Controlled Activation of Ruthenium-Catalyzed Ammonia Borane Hydrolysis. ACS Catal. 2015, 5, 1726-1735. [CrossRef]

71. Gao, M.Y.; Yang, W.W.; Yu, Y.S. Monodisperse PtCu alloy nanoparticles as highly efficient catalysts for the hydrolytic dehydrogenation of ammonia borane. Int. J. Hydrogen Energy 2018, 43, 14293-14300. [CrossRef]

72. Xu, D.; Wang, W.D.; Tian, M.; Dong, Z.P. Immobilization of Pt nanoparticles in hollow mesoporous silica nanocapsules: An aggregation- and leaching-resistant catalyst. J. Colloid Interface Sci. 2018, 516, 407-415. [CrossRef] [PubMed]

(C) 2019 by the authors. Licensee MDPI, Basel, Switzerland. This article is an open access article distributed under the terms and conditions of the Creative Commons Attribution (CC BY) license (http://creativecommons.org/licenses/by/4.0/). 